\title{
Genetic Divergence in Black Gram [Vigna mungo (L.) Hepper]
}

\author{
Bommana Suvarchala*, Hemlata Sharma, N. S. Dodiya, \\ Bhavana Goswami and Deeksha Chauhan
}
Department of Genetics and Plant Breeding, Rajasthan College of Agriculture, Maharana Pratap University of Agriculture and Technology (MPUAT), Udaipur, Rajasthan, India

*Corresponding author

\begin{tabular}{l} 
K e y w o r d s \\
Black gram, \\
Variability, \\
Correlation, Path \\
analysis, Genetic \\
divergence and \\
Cluster analysis \\
\hline Article Info \\
\hline $\begin{array}{l}\text { Accepted: } \\
\text { 26 September } 2020 \\
\text { Available Online: } \\
\text { 10 October } 2020\end{array}$ \\
\hline
\end{tabular}

gram,

Correlation, Path analysis, Genetic

divergence and

Cluster analysis

\section{Article Info}

Accepted:

Available Online.

\section{A B S T R A C T}

\begin{abstract}
The present study entitled "Genetic Divergence in Black gram [Vigna mungo (L.) Hepper]" was conducted with 56 genotypes and two checks namely Pant U-31 and Pratap Urd-1during Kharif- 2019 at the Experimental farm, RCA, MPUAT, Udaipur. The genotypes were planted in augmented RBD design in four blocks. Mean squares due to genotypes were significant for plant height, number of branches per plant, number of pods per plant and pod length out of twelve characters as divulge from ANOVA. Present investigation results revealed that character seed yield per plant showed high GCV, heritability and genetic gain. Maximum heritability was found for pod length followed by plant height, number of branches per plant, number of pods per plant and seed yield per plant. While, maximum genetic gain was observed for seed yield per plant followed by number of pods per plant, number of branches per plant, plant height and biological yield. In general, PCV was higher than GCV for all the characters. Seed yield per plant was significant positively correlated at both genotypic as well as phenotypic levels with number of branches per plant, number of pods per plant, pod length, number of seed per pod, biological yield and harvest index. In cluster analysis, black gram genotypes were divided into VI clusters. Average inter cluster distance values were maximum between cluster V and VI (34.298). Cluster VI possessed genotypes with early flowering and maturity, plant height, number of branches per plant, pod length and harvest index From, the present investigation it can be concluded that genotypes KPU-129-104, RBU-38, KU16-89, KU-16-96, KPU-1098, TBU-2, KPU-11-37 appeared promising Presence of significant genetic variability and diversity among the tested genotypes of urdbean would be favorable for obtaining superior progenies in future breeding programme.
\end{abstract}

\section{Introduction}

Black gram (Vigna mungo L. Hepper, 2n=22), popularly known as urd bean, Urid or Mash, is an important self-pollinating diploid grain legume (Naga et al., 2006) and belongs to the family Leguminosae and subfamily Papilionaceous. India is the primary centre of origin (Vavilov, 1926). It has been in cultivation from ancient times and is one of 
the most highly prized pulse crops of India. It is an economically important grain legume crop in Asia, widely cultivated on marginal lands with low inputs during Kharif, Rabi and Summer seasons. It is also an excellent green manure and soil conservation crop. Dehusked cotyledon is used for the preparation of fermented foods such as idli, dosa, and nonfermented foods like cooked dal, hopper, papad and waries (spicy hollow balls) (Batra and Millner, 1974). It is highly nutritious and is recommended for diabetic patients. Whole black gram is a rich source of protein, fibre, several vitamins and essential minerals such as calcium and iron (Reddy et al., 1982).

Black gram is the fourth main pulse crop in India. Total pulse production in India is estimated to $24.51 \mathrm{MT}$ whereas total production of Urd bean is recorded as 3.28 MT (DES, 2017-18). In India, black gram is cultivated in 5.031 Mha with a total production of about $0.653 \mathrm{M}$ tonnes. It is mostly grown in Andhra Pradesh, Uttar Pradesh, Maharashtra, Madhya Pradesh, Tamil Nadu, Rajasthan, Odisha and Bihar.

Assessment of variability is an initial step in any breeding programme. Higher the diversity of the material, better are the chances of improvement, provided that heritability and genetic advance is more. The ultimate goal of any breeding programme is to get higher yield. Correlation and Path analysis assists in evaluating yield contributing characters for selection. $\mathrm{D}^{2}$ analysis has been found most effective and therefore, widely used for the classification of parental lines.

\section{Materials and Methods}

The present investigation was carried out during the kharif season of 2019 at Experimental farm, Rajasthan College of Agriculture, Udaipur is located at $24^{0} 35^{\prime} \mathrm{N}$ latitude and $73^{\circ} 42^{\prime} \mathrm{E}$ longitude and located at an elevation of 582.17 meters above mean sea level. The climatic conditions of that area were subtropical condition with humid climate. The soil of experimental field was clay loam, deep, well drained, alluvial in origin and has fairly good moisture holding capacity. The experiment was conducted in augmented RBD design with experimental material consists of fifty-six genotypes along with two check varieties (Pant U-31, Pratap Urd-1) of black gram were collected from Agriculture Research Station, Kota. Each genotype was sown in two rows with the spacing of $30 \mathrm{~cm}$ row to row and $10 \mathrm{~cm}$ plant to plant. Standard package of practices were followed to raise the crop. Observations were recorded on randomly selected five competitive plants for plant height, number of branches per plant, number of pods per plant, pod length, number of seeds per pod, seed yield per plant, 100 seed-weight, biological yield per plant, harvest index, and protein content. Whereas observation for days to 50 per cent flowering and days to maturity were recorded on plot basis.

The pooled experimental data were used for statistical analysis by using MS EXCEL and OPSTAT online software. Analysis of variance by Federer (1956) for augmented RBD Genotypic coefficient of variation (GCV) and phenotypic coefficient of variation (PCV) by Burton (1952). Heritability by Burton and De-Vane (1953).Genetic Gain by Johnson et al., (1955). Since, experimental design was augmented therefore, diversity analysis was carried out using ward (1963) method using Euclidian distances and calculated through SPSS version 19.

\section{Results and Discussion}

Mean squares due to genotypes were significant for plant height, number of branches per plant, number of pods per plant and pod length out of twelve characters as 
divulge from ANOVA representing some amount of genetic variability among the genotypes under study. Genotypes revealed variation for different characters viz., days to 50 per cent flowering (37 to 43 days), days to maturity (79 to 83 days), plant height (28.32 to $43.39 \mathrm{~cm}$ ), number of branches per plant (5.99 to 12.01), number of pods per plant (14.75 to 36.12 ), pod length (4.00 to 5.65 $\mathrm{cm}$ ), number of seeds per pod (4.24 to 7.12), seed yield per plant (2.03 to $5.56 \mathrm{~g}$ ), seed weight (3.70 to $5.38 \mathrm{~g})$, biological yield per plant $(8.15$ to $18.59 \mathrm{~g})$, harvest index (12.94 to $51.63 \%)$ and protein content (18.37 to $27.97 \%)$.

Overall, PCV was higher than GCV for all characters indicating little influence of environment on phenotype (Table 1). Ramya et al., (2014) and Priyanka et al., (2016) also reported in earlier findings. High magnitude of GCV\& PCV (> 20\%) for seed yield per plant (22.81 \%)by Patel et al., (2014),Kumar et al., (2015), Babu et al., (2016), Mahesha and Lal (2017), Ozukum and Sharma (2017), Kuralarasan et al., (2018) and Priya et al., (2018). Moderate (10-20\%) for number of pods per plant $(17.39 \%)$, biological yield per plant $(14.26 \%)$, harvest index (14.14\%), number of branches per plant $(13.10 \%)$ and plant height $(10.84 \%)$. For pod length (8.67 $\%)$, number of seeds per pod $(7.23 \%), 100-$ seed weight $(2.88 \%)$, seed protein content $(2.22 \%)$, days to 50 per cent flowering (2.97 $\%)$ and days to maturity $(1.00 \%)$ both GCV and PCV estimates were found low $(<10 \%)$. For harvest index estimates of GCV was moderate but PCV was found high by Bandi et al., (2018).

Table.1 Estimation of variability parameter

\begin{tabular}{|c|l|c|c|c|c|c|}
\hline $\mathbf{S N}$ & \multicolumn{1}{|c|}{ Character } & GCV & PCV & $\mathbf{h}^{2}$ & GA & GG \\
\hline 1 & $\begin{array}{l}\text { Days to 50 per cent } \\
\text { flowering }\end{array}$ & 2.97 & 3.70 & 64.37 & 1.98 & 4.90 \\
\hline 2 & Days to maturity & -1.00 & 1.39 & -19.60 & -0.45 & -0.56 \\
\hline 3 & Plant height (cm) & 10.84 & 11.00 & 97.06 & 8.11 & 22.00 \\
\hline 4 & $\begin{array}{l}\text { Number of branches per } \\
\text { plant }\end{array}$ & 13.10 & 13.42 & 95.34 & 2.47 & 26.36 \\
\hline 5 & Number of pods per plant & 17.39 & 17.98 & 93.52 & 8.07 & 34.64 \\
\hline 6 & Pod length (cm) & 8.67 & 8.71 & 99.12 & 0.84 & 17.78 \\
\hline 7 & Number of seed per pod & 7.23 & 8.26 & 76.79 & 0.79 & 13.06 \\
\hline 8 & Seed yield per plant (g) & 22.81 & 25.06 & 82.81 & 1.58 & 42.76 \\
\hline 9 & 100-Seed weight (g) & 2.88 & 8.26 & 12.13 & 0.09 & 2.06 \\
\hline 10 & Biological yield (g) & 14.26 & 19.66 & 52.60 & 2.83 & 21.30 \\
\hline 11 & Harvest index (\%) & 14.14 & 21.51 & 43.23 & 5.38 & 19.15 \\
\hline 12 & Seed protein content (\%) & 2.22 & 9.87 & 5.07 & 0.24 & 1.03 \\
\hline
\end{tabular}


Table.2 Genotypic (above diagonal) and phenotypic (below diagonal) correlation coefficient matrix for different characters in black gram

\begin{tabular}{|c|c|c|c|c|c|c|c|c|c|c|c|c|c|}
\hline SN & Character & $\begin{array}{c}\text { Days to } 50 \\
\text { per cent } \\
\text { flowering }\end{array}$ & $\begin{array}{l}\text { Days } \\
\text { to } \\
\text { matur } \\
\text { ity }\end{array}$ & $\begin{array}{c}\text { Plant } \\
\text { height } \\
\text { (cm) }\end{array}$ & $\begin{array}{c}\text { Number } \\
\text { of } \\
\text { branches } \\
\text { per plant }\end{array}$ & $\begin{array}{c}\text { Number } \\
\text { of pods } \\
\text { per plant }\end{array}$ & $\begin{array}{c}\text { Pod } \\
\text { length } \\
\text { (cm) }\end{array}$ & $\begin{array}{l}\text { Number } \\
\text { of seed } \\
\text { per pod }\end{array}$ & $\begin{array}{c}\text { Seed } \\
\text { yield } \\
\text { per } \\
\text { plant } \\
(\mathrm{g})\end{array}$ & $\begin{array}{c}\text { 100-Seed } \\
\text { weight }(g)\end{array}$ & $\begin{array}{l}\text { Biological } \\
\text { yield (g) }\end{array}$ & $\begin{array}{c}\text { Harvest } \\
\text { index }(\%)\end{array}$ & $\begin{array}{c}\text { Seed } \\
\text { protein } \\
\text { content } \\
(\%)\end{array}$ \\
\hline 1 & Days to 50 per cent flowering & & 9.00 & 0.04 & -0.19 & 0.01 & -0.14 & 0.13 & 0.13 & $0.59 * *$ & $-0.36 * *$ & $0.80 * *$ & $0.71 * *$ \\
\hline 2 & Days to maturity & $0.51^{* *}$ & & 9.00 & 9.00 & 9.00 & 9.00 & 9.00 & 9.00 & 9.00 & 9.00 & 9.00 & 9.00 \\
\hline 3 & Plant height $(\mathrm{cm})$ & 0.04 & 0.01 & & 0.17 & $0.35 * *$ & 0.07 & 0.16 & 0.19 & $0.52 * *$ & $0.63 * *$ & $-0.45^{* *}$ & $-0.52 * *$ \\
\hline 4 & Number of branches per plant & -0.06 & 0.01 & 0.17 & & $0.62 * *$ & 0.04 & 0.21 & $0.56^{* *}$ & $0.53 * *$ & $0.74 * *$ & 0.24 & 1.45 \\
\hline 5 & Number of pods per plant & 0.14 & 0.22 & $0.35^{* *} *$ & $0.61 * *$ & & 0.06 & 0.07 & $0.53 * *$ & -0.04 & 1.07 & -0.26 & $0.69 * *$ \\
\hline 6 & Pod length $(\mathrm{cm})$ & -0.12 & 0.03 & 0.05 & 0.03 & 0.05 & & $0.44 * *$ & $0.40 * *$ & 0.25 & 0.26 & $0.39 * *$ & -0.14 \\
\hline 7 & Number of seed per pod & 0.07 & -0.12 & 0.06 & 0.17 & 0.00 & $0.43 * *$ & & $0.49 * *$ & -0.23 & -0.00 & $0.93 * *$ & -1.34 \\
\hline 8 & Seed yield per plant (g) & 0.05 & -0.13 & 0.10 & $0.47 * *$ & $0.42 * *$ & $0.40 * *$ & $0.58 * *$ & & -0.13 & $0.73 * *$ & $0.92 * *$ & $-0.95 * *$ \\
\hline 9 & 100-Seed weight (g) & -0.21 & $-0.34 *$ & 0.07 & 0.03 & -0.20 & 0.16 & 0.23 & $0.28 *$ & & $0.69 * *$ & -1.34 & $-9.03 * *$ \\
\hline 10 & Biological yield (g) & 0.05 & 0.10 & $0.37 * *$ & $0.61 * *$ & $0.79 * *$ & 0.22 & 0.23 & $0.63 * *$ & 0.14 & & $0.39 * *$ & $-0.33^{*}$ \\
\hline 11 & Harvest index (\%) & 0.04 & -0.21 & $-0.28 *$ & -0.00 & $-0.28 *$ & $0.27 *$ & $0.50 * *$ & $0.60 * *$ & 0.17 & -0.21 & & -1.36 \\
\hline 12 & Seed protein content $(\%)$ & 0.07 & 0.23 & -0.22 & 0.18 & 0.11 & 0.03 & -0.01 & 0.12 & -0.04 & 0.05 & 0.11 & \\
\hline
\end{tabular}

Table.3 Number of black gram genotypes in each Cluster

\begin{tabular}{|c|c|c|}
\hline Cluster & Number & Members \\
\hline I & 12 & $\begin{array}{l}\text { KPU-1115, KPU-12-1733, KPU-12-1730A, KPU-11-46, KPU-11- } \\
\text { 47, KPU-12-197, Pant U-40, KU-16-92, KU-16-98, KU-16-102, } \\
\text { KPU-12-496, GPU-KPU-1137 }\end{array}$ \\
\hline II & 9 & $\begin{array}{l}\text { KPU-96-3, AKU-1302, AKU-11-9, AKU-11-15, AKU-11-21, AKU- } \\
11-23 \text {, AKU-14-02, KU-16-6, KU-16-9 }\end{array}$ \\
\hline III & 4 & KPU-216 * PU-40F 5 , KPU-525-64, AKU-12-3, GPU-KPU-1143 \\
\hline IV & 20 & $\begin{array}{l}\text { KPU-1016, KPU-12-213A, KPU-11-15, KPU-11-18, KPU-11-22, } \\
\text { KPU-514-75, KPU-524-65, KPU-07408, KPU-11-43, AKU-1604, } \\
\text { AKU-11-3, AKU-13-3, KU-16-3, KU-16-8, KU-16-11, KU-16-13, } \\
\text { KU-16-90, KU-16-95, KPU-1127, Pant Urd-1 }\end{array}$ \\
\hline $\mathbf{V}$ & 1 & KPU-11-37 \\
\hline VI & 10 & $\begin{array}{l}\text { KPU-129-104, KPU-11-39, RBU-38, KU-16-87, KU-16-89, KU-16- } \\
\text { 96, KU-16-97, KPU-1098, TBU-2, TBU-3 }\end{array}$ \\
\hline
\end{tabular}

Table.4 Average intra and inter-cluster Euclidian distances in 56 genotypes of black gram

\begin{tabular}{|l|l|l|l|l|l|l|}
\hline Cluster & I & II & III & IV & V & VI \\
\hline I & $\mathbf{6 . 0 3}$ & 11.974 & 10.813 & 9.016 & 24.890 & 10.871 \\
\hline II & & $\mathbf{5 . 6 5}$ & 17.042 & 7.183 & 29.494 & 11.400 \\
\hline III & & & $\mathbf{6 . 3 9}$ & 11.950 & 16.443 & 18.912 \\
\hline IV & & & & $\mathbf{4 . 9 9}$ & 26.442 & 9.703 \\
\hline V & & & & & $\mathbf{0 . 0 0}$ & 34.298 \\
\hline VI & & & & & & $\mathbf{5 . 5 5}$ \\
\hline
\end{tabular}


Figure.1 Dendrogram of 56 genotypes of Black gram

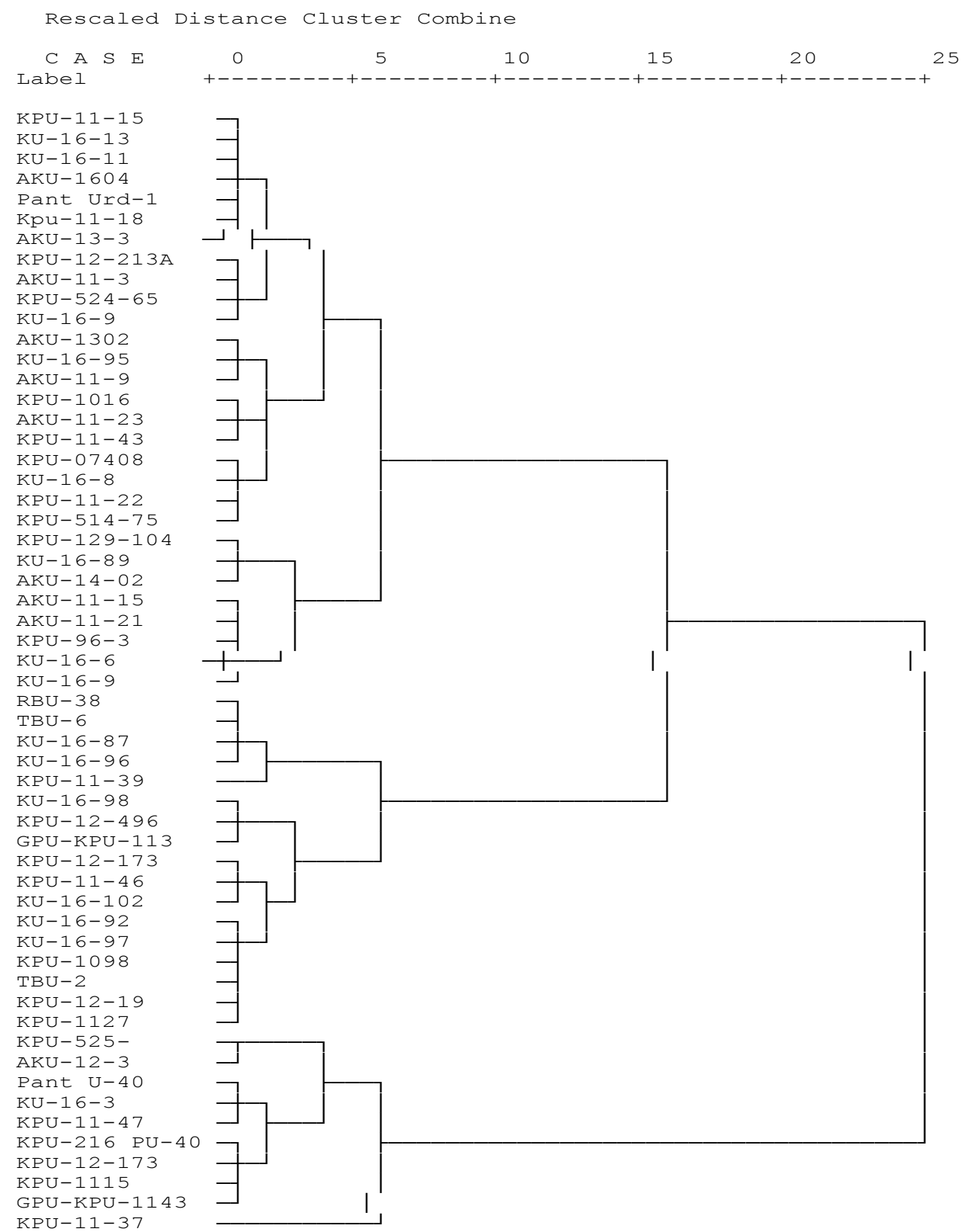

Maximum heritability in broad sense (>80\%) was found for pod length (99.12\%), plant height $(97.06 \%)$, number of branches per plant (95.34\%), number of pods per plant $(93.52 \%)$ and seed yield per plant (82.81 $\%)$ and Very Low $(<60 \%)$ heritability in days to maturity. High genetic gain $(>20 \%)$ was recorded for seed yield per plant $(42.76 \%)$ followed by number of pods per plant(34.64 $\%)$, number of branches per plant $(26.36 \%)$, plant height $(22.00 \%)$ and biological yield $(21.30 \%)$. High heritability coupled with high genetic gain were reported by $\mathrm{Babu}$ et al., (2016), Gowsalya et al., (2016), Kuralarasan et al., (2018), Priya et al., (2018), Sushmitharaj et al., (2018), Tank et al., (2018). It indicates the involvement of additive gene effects and selection would be effective for improvement of this character. Generally, moderate to high heritability in 
broad sense coupled with moderate to high genetic gain stipulated the involvement of additive gene action, suggesting scope of improvement in these characters through selection.

Correlation coefficient analysis gives significant mutual relationship among various characters and yield so that selection can be more efficient to attain the goal of genetic improvement of crop for a complex trait like yield. Galton (1889) gave the concept of correlation coefficient and later on it was elaborated by Fisher (1918) and Fisher and Yates (1938). The phenotypic and genotypic correlation coefficients of all the characters were worked-out as per Al-Jibouri et al., (1958). The study revealed that seed yield per plant showed significant positive correlation at both genotypic and phenotypic levels with number of branches per plant $\left(\mathrm{rg}=0.56^{* *}, \mathrm{rp}=\right.$ $\left.0.47^{* *}\right)$, number of pods per plant $\left(\mathrm{rg}=0.53^{* *}\right.$, $\mathrm{rp}=0.42^{* *}$, pod length $\left(\mathrm{rg}=0.40^{* *}, \mathrm{rp}=\right.$ $\left.0.40^{* *}\right)$, number of seed per pod $\left(\mathrm{rg}=0.49^{* *}\right.$, $\left.\mathrm{rp}=0.58^{* *}\right)$, biological yield $\left(\mathrm{rg}=0.73^{* *}, \mathrm{rp}=\right.$ $\left.0.63^{* *}\right)$ and harvest index $\left(\mathrm{rg}=0.92^{* *}, \mathrm{rp}=\right.$ $0.60^{* *}$ ) and only at phenotypic level with 100 seed weight $\left(\mathrm{rp}=0.28^{*}\right)$. It exhibited significant negative correlation only at genotypic level with seed protein content ( $\mathrm{rg}$ $=-0.95^{* *}$ ) (Table 2). Similar findings are in line with Bharati et al., (2013), Patel et al., (2014), Mathivathana et al., (2015), Mehra et al., (2016), Blessy and Naik (2018), Hadamani et al., (2019) and Sathees et al., (2019).

Path analysis is defined as simple standard partial regression coefficient which splits the correlation coefficient into the measure of direct and indirect effects of a set of component characters on the chief dependent variable. Path analysis was initially advocated by Wright (1921) and was further elaborated for plant breeding by Dewey and Lu (1959). Since, in the present investigation, the mean sum of squares due to genotype was not significant for seed yield per plant. Therefore, path analysis was not carried out as dependent variable yield is not significantly variable among them.

Genetic diversity is an important pre-requisite in selecting parents for hybridization and evolving high yielding genotyping in any crop breeding programme. $\mathrm{D}^{2}$ analysis has been found most effective and therefore, widely used for the classification of parental lines. The concept of $\mathrm{D}^{2}$ analysis was initially developed by P.C. Mahalanobis in 1928 but the application of this technique for the assessment of genetic diversity in plant breeding was advised by Rao (1952). The number of genotypes varied in each cluster from one to twenty. Fifty-six genotypes were grouped into VI clusters on the basis of pragmatic distance between genotypes within a cluster as related to genotypes in other cluster in Table 3. The maximum intra cluster distance was observed in cluster III (6.39) followed by in cluster I (6.03), cluster II (5.65), cluster VI (5.55) and cluster IV (4.99). Maximum inter cluster distance was observed between cluster V and VI (34.298). Cluster VI possessed genotypes with early flowering and maturity, plant height, number of branches per plant, pod length and harvest index (Table 4). Similar results were reported by Bharti et al., (2014), Geethanjali et al., (2014), Hadimani et al., (2016), Kamannavar et al., (2016), Reddy et al., (2018), Vidhya et al., (2018), Vyas et al., (2018), Gopinath et al., (2018) regarding maximum and minimum intra and inter cluster distances in black gram.The genotypes belonging to different clusters revealed divergence for different traits and could be successfully employed in hybridization programme for desirable transgressive segregants. Therefore, crosses between members of high cluster means coupled with high inter-cluster distances among them are likely to be more rewarding. 
In conclusion, from the present investigation it can be concluded that genotypes KPU-129104, RBU-38, KU-16-89, KU-16-96, KPU1098, TBU-2, KPU-11-37 appeared promising. Presence of significant genetic variability and diversity among the tested genotypes of urdbean would be conducive for obtaining superior progenies in future breeding programme.

\section{References}

Al-Jibouri, H.A., Miller, P.A. and Robinson, H.F. 1958. Genotypic and environmental variance in upland cotton of interspecific origin. Journal of Agronomy, 50: 633-635.

Babu, J.S., Reni, Y.P. and Ramana, M.V. (2016). Character correlation and path coefficient in Black gram [Vigna mungo (L.) Hepper]. Int. Res. J. Nat. App. Sci, 3: 178-185.

Bandi, H.R.K., Rao, K.N., Krishna, K.V. and Srinivasulu, K. (2018). Variability, Heritability and Genetic Advance for Quantitative Characters in Rice Fallow Black gram [Vigna mungo (L.) Hepper]. Int. J. Curr. Microbiol. App. Sci, 7(2):171-176.

Batra, L.R. and Millner, P.D. (1974). Some Asian fermented foods and beverages, and associated fungi. Mycologia, 66: 942-950.

Bharti, B., Kumar, R., Bind, H.N., Kumar, A. and Sharma, V. (2013). Correlation and path analysis for yield and yield components in black gram [Vigna mungo (1.) Hepper]. Society for Sci. Dev. in Agric. and Tech, 473-476

Blessy, V. and Naik, B.P. (2018). Studies on Correlation and Path Analysis in Blackgram (Vigna mungo (L.) Hepper). Int. J. Curr. Microbiol. App. Sci, 7(8): 1991-1997.

Burton, G.M. (1952) Quantitative inheritance in grasses. Sixth International
Grassland Congress, 1:277-283.

Burton, G.W. and De vane, E.M. (1953). Estimating heritability in tall fescue (Festuca arundinacea) from replicated clonal material. Agron. J., 45:478-48.

DES, (2017-18). Crop-wise, III and IV Advanced Estimates of Pulse Crop Production, DOA, Co-Op and FW, GOR, (Raj).

Dewey, D.R. and Lu, K.H. (1959). A correlation and path coefficient analysis of components of wheat grass seed production. Agron. J., 51: 515518.

Federer, W. T. (1956). a. Augmented designs. Hawaiian Planters Record, 55:191208.

Fisher R. A. (1918). The correlation between relatives on the supposition of Mendelian inheritance. Transactions of the Royal Society of Edinburgh,52: 399-433.

Fisher, R. A. and Yates, F., (1953). Statistical tables for agricultural, biological and medical research. Edinborough, Oliver and Boyd.

Galton F. (1889). Natural inheritance. Macmillan, London.

Geethanjali, Anuradha, C. and Suman (2015). Genetic Diversity for Yield and its Components in Black gram (Vigna mungo L.). Int. J. Sci. Res, 4(8): 563565.

Gopinath, M.P., Desai, S.S., Palshetkar, M.G., Harun, H.A. and RajeMahadik, V.A.(2018). Evaluation of Genetic Divergence in Black gram [Vigna mungo (L.) Hepper]. Int. J. Curr. Microbiol. App. Sci, 7(8): 472-479.

Gowsalya, P., Kumaresan, D., Packiaraj, D. and Bapu, R.J.K. (2016). Genetic variability and character association for biometrical traits in Black gram (Vigna mungo (L.) Hepper). Electron. J. Plant Breed, 7(2): 975-928.

Hadimani, A.; Konda, C. R.; Nidagundi, J. M. 
and Patil, R. (2016). Genetic diversity analysis in Black gram [Vigna mungo (L.) Hepper] based on quantitative traits. Green Farming, 3:598-601.

Johnson, H.W., Robinson, H.F. and Comstock, R.F. (1955). Estimation of genetic environmental variability in soybean. Agron. J., 47: 314-318.

Kamannavar, P.Y., Revanappa, S.B., Vijaykumar, A.G., Basamma, K. and Ganajaxi. (2016). Nature of genetic diversity for seed yield and its component traits in urd bean [Vigna mungo (L.) Hepper]. Indian J. Agric. Res., 50(1): 96-98.

Kumar, G. V., Vanaja, M., Lakshmi, N. J. and Maheshwari, M. (2015). Studies of variability, heritability and genetic advance for quantitative traits in black gram (Vigna mungo (L.) Hepper). Agric. Res. J., 52(4):28-31.

Kuralarasan, V., Vanniarajan, C., Kanchana, S., Veni, K. and Anandhi Lavanya, S. 2018. Genetic divergence, heritability and genetic advance in mutant lines of urdbean [Vigna mungo (L.) Hepper]. Legume Res., 41: 833-836.

Mahalanobis, P.C. (1928). On the generalised distance in statistics. Proc. Nat. Acad. Sci., 19: 201-208.

Mahesha, H.S. and Lal, G.M. (2017). Studies on genetic diversity in Blackgram (Vigna mungo L. Hepper) germplasm. Int. J. Adv. Biol. Res., 7 (3):426-434.

Mathivathana, M., Shunmugavalli, N., Muthuswamy, A. and Harris, C.V. (2015). Correlation and path analysis in black gram. Agricultural Research Communication Centre, 35: 158-160.

Mehra, R., Tikle, A.N., Saxena, A., Munjal, A. and Singh, M. (2016). Correlation, path coefficient and genetic diversity in black gram (Vigna mungo (L.) Hepper). Int. Res. J. Pl. Sci., 7:1-11.

Naga, N., Sharma, S.K. and Kant, A. (2006). Agronomic evaluation of some induced mutants of urd bean (Vigna mungo (L.) Hepper). SABRAO Journal Breeding and Genetics, 38: 29-38.

Ozukum, C. and Sharma, M.B. 2017. Variability among urdbean (Vigna mungo L. Hepper) for yield and yield components. International Journal of Research and Innovation in Applied Science, 2:26-28.

Patel, S.R., Patel, K.K. and Parmar, H.K. (2014). Genetic variability, correlation and path analysis for seed yield and its components in green gram (Vigna radiata (L.) Wilczek). Int. J. Life Sci., 9: 1847-1852.

Priya, L., Arumugam Pillai, M., Shoba, D., Kumari, S.M.P. and Aananthi, N. 2018. Genetic variability and correlation studies in blackgram [Vigna mungo (L.) Hepper]. Electronic Journal of Plant Breeding, 9: 1583-1587.

Priyanka, S. Rangaiah, S. and Babu, B.M.S. (2016). Genetic variability estimates of quantitative and qualitative traits in black gram. Int. J. Agric. Sci., 8(40):1821- 1824.

Ramya, B., Nallathambi, G. and Ram, S.G. (2014). Genetic variability, heritability and Genetic advance in induced mutagenesis black gram (Vigna mungo (L.) Hepper). Plant Archives, 14(1):139-141.

Rao, C. R., 1952. Advanced Statistical Methods in Biometrical Research, John Wiley and Sons, New York.

Reddy, A.K., Priya, M.S., Reddy, D.M. and Reddy, B.R. (2018). Genetic Divergence Studies in Black gram (Vigna mungo (L.) Hepper), Int. J. Pure App. Biosci., 6(5): 232-237.

Reddy, N.R., Salunkhe, D.K., Sathe, S.K. and Samuel Kon (1982). Biochemistry of black gram (Phaseolus mungo L.): A review. CRC Critical Reviews in Food Science and Nutrition, 16: 49-114. 
Sathees, N.D, Shoba, S. Saravanan, Kumari, S.M.P. and Pillai, M.A. (2019). Studies on Genetic Variability, Association and Path Coefficient Analysis in Black Gram (Vigna mungo L. Hepper). Int. J. Curr. Microbiol. App. Sci., 8(06): 1892-1899.

Sushmitharaj, D.V., Shoba, D. and Pillai, M.A. (2018). Genetic Variability and Correlation Studies in Black Gram (Vigna mungo [L.] Hepper) with reference to YMV Resistance. Int. J. Curr. Microbiol. App. Sci, 6: 28492856.

Tank, H.K., Sharma, P.P., Nagar, K.K., Bairwa, L.L. and Meghawal, D.R. (2018). Genetic variability and heritability studies in blackgram [Vigna mungo (L.) Hepper]. Int. J. Chem. Stud., 6(6): 642-64.
Vavilov, N.I. (1926). Origin variation, immunity of cultivated plants. Chronica Bot., 13: 364.

Vidya, S.S., Sabesan, T. and Saravanan, K. (2018). Genetic Divergence studies in Blackgram (Vigna mungo L.) for yield and quantitative traits. Journal of Phytology, 10: 24-26.

Vyas, D., Joshi, A. and Kedar, O.P. (2018). Genetic diversity analysis of black gram (Vigna mungo L.) J. Pharmacogn. Phytochem., 7(3): 25352538.

Ward J. H. (1963). Hierarchical grouping to optimize an objective function. Journal of the American Statistical Association, 58:236-344.

Wright, S. (1921). Correlation and Causation. J. Agri. Res., 20:2528.

\section{How to cite this article:}

Bommana Suvarchala, Hemlata Sharma, N. S. Dodiya, Bhavana Goswami and Deeksha Chauhan. 2020. Genetic Divergence in Black Gram [Vigna mungo (L.) Hepper]. Int.J.Curr.Microbiol.App.Sci. 9(10): 3666-3674. doi: https://doi.org/10.20546/ijcmas.2020.910.424 